\title{
MENINGKATKAN PEREKONOMIAN IBU RUMAH TANGGA DENGAN MENUMBUHKAN MINAT BERWIRAUSAHA DI MASA PANDEMI COVID-19
}

\author{
IMPROVING THE ECONOMY OF HOUSEWIVES BY FOSTERING \\ ENTREPRENEURIAL INTEREST DURING THE COVID-19 PANDEMIC
}

\section{Astri Handari $^{{ }^{*}}$, Indi Ramadhani ${ }^{1}$, Tine Badriatin ${ }^{2}$, Tasya Khoerunnisa Hijriah $^{1}$, Aulia Azizatul Jannah ${ }^{1}$}

\author{
${ }^{1}$ Prodi Manajemen, Universitas Siliwangi, astrihandari58@gmail.com \\ ${ }^{2}$ Prodi Keuangan dan Perbankan, Universitas Siliwangi, tinebadriatin@gmail.com \\ *Email: tinebadriatin@gmail.com
}

(Diterima 12-01-2021; Disetujui 22-02-2021)

\begin{abstract}
ABSTRAK
Universitas Siliwangi sebagai lembaga pendidikan yang melaksanakan Kuliah Kerja Nyata (KKN) Mandiri. KKN Mandiri merupakan suatu program kuliah yang bersifat pengabdian kepada masyarakat yang posisinya berada di tengah pandemi seperti saat ini dengan tujuan untuk membentengi penyebaran virus Corona (Covid-19) di lingkungan masyarakat, membangun mahasiswa menjadi mahasiswa yang berkarakter, memiliki jiwa yang empati terhadap sesama, dan memperkuat kepekaan mahasiswa terhadap permasalahan yang ada di lingkungan sekitar. KKN Mandiri dalam rangka pencegahan virus corona dan sebagai pemberdayaan masyarakat melalui pengenalan konsep kewirausahaan di daerah Kota Tasikmalaya, salah satunya di Perum Bumi Endah Residence, Kelurahan Parakannyasag, Kecamatan Indihiang, merupakan perumahan yang terbilang cukup baru dibangun yang mempunyai 205 Kepala Keluarga. Tujuan kegiatan di Perumahan Bumi Endah Residence adalah meningkatkan perekonomian ibu rumah tangga (IRT) dengan menumbuhkan minat berwirausaha di masa pandemi Covid-19. Di perumahan ini sendiri sudah terdapat beberapa IRT yang mulai berwirausaha, hanya saja sebagain IRT lainnya hanya diam saja. Mengingat saat ini sedang terjadi pandemi sehingga IRT tersebut diberikan solusi untuk berbisnis sekaligus memecahkan permasalahan perekonomian keluarga. Pengabdian ini menggunakan metode penyuluhan yang dihadiri oleh 5 orang IRT Perum Bumi Endah Residence. Bertujuan untuk memberikan bekal wawasan dan pemahaman mengenai konsep wirausaha di masa pandemi. Hasil dari kegiatan ini adalah memproduksi face shield sebagai solusi dari permasalahan sebagian kalangan orang sakit yang merasa pengap saat memakai masker kain.
\end{abstract}

Kata Kunci : berwirausaha, pandemi covid-19

\begin{abstract}
Siliwangi University as an educational institution that carries out Independent Real Work Lectures (KKN). KKN Mandiri is a community service program whose position is in the midst of a pandemic as it is today with the aim of fortifying the spread of the Corona Virus (Covid-19) in the community, building students into students with character, having a spirit of empathy for others, and strengthen student sensitivity to problems in the environment. Independent KKN in the framework of preventing the corona virus and as community empowerment through the introduction of the concept of entrepreneurship in the City of Tasikmalaya, one of which is at Perum Bumi Endah Residence, Parakannyasag Village, Indihiang District, which is a fairly new housing that has 205 heads of families. The focus we take at Bumi Endah Residence Housing is to improve the economy of housewives by fostering interest in entrepreneurship during the Covid-19 pandemic. In this housing estate itself, there are already several IRTs who have started entrepreneurship, it's just that some of the other IRT are just silent. Given that currently there is a pandemic so that the IRT is given a solution to doing business as well as solving family economic problems. This service uses the counseling method which was attended by 5 IRT Perum Bumi Endah Residence. Aims to provide insight and understanding of the concept of entrepreneurship during a pandemic. The result of this activity is to produce face shields as a solution to the problems of some sick people who feel stuffy when wearing cloth masks.
\end{abstract}

Keywords: entrepreneurship, covid-19 pandemic 
Meningkatkan Perekonomian Ibu Rumah Tangga dengan Menumbuhkan Minat Berwirausaha di Masa Pandemi Covid-19

Astri Handari, Indi Ramadhani, Tine Badriatin, Tasya Khoerunnisa Hijriah, Aulia Azizatul Jannah

\section{PENDAHULUAN}

Di zaman milennial ini, pengembangan usaha UMKM dapat dilakukan melalui beberapa cara seperti penyuluhan melalui pengembangan kreatifitas produk dan pemasaran produk baik secara offline maupun online. Pengetahuan terkait kewirausahaan sangat diperlukan pada saat ini. Mengingat masyarakat khususnya ibu rumah tangga yang tidak memiliki penghasilan tambahan, namun memiliki potensi yang besar dalam mendukung kehidupan ekonomi keluarga, di sisi lain masih banyak ibu rumah tangga yang belum memiliki kesadaran dan minat untuk berwirausaha. Pelatihan kewirausahaan ini merupakan salah satu solusi yang dapat ditawarkan untuk mewujudkan hal tersebut. Kewirausahaan adalah suatu sikap, jiwa dan kemampuan untuk menciptakan sesuatu yang baru yang sangat bernilai dan berguna bagi dirinya dan orang lain. Kewirausahaan merupakan sikap mental dan jiwa yang selalu aktif atau kreatif, berdaya, bercipta, berkarya dan bersahaja dan berusaha dalam rangka meningkatkan pendapatan dalam kegiatan usahanya (Isrososiawan, 2013). Ibu rumah tangga mampu membantu memperbaiki perekonomian dengan menjadi seorang wirausahawan. Menurut Norman M. Scarborough dan Thomas W. Zimmerer (1993), “An entrepreneur isone who creates a new business in the face if risk and uncertaintyfor the purpose of achievingprofit and growth by identifying opportunities and asembling the necessary resources to capitalizeon those opportunities" (Isrososiawan, 2013). Berdasarkan keinginan untuk memberikan manfaat yang lebih besar bagi ibu rumah tangga maka dengan segenap pengalaman, pengetahuan, dan berbagai hasil survei serta konsultasi, kami melakukan penyuluhan tentang pembuatan face shield serta business education. Kegiatan ini diharapkan mampu menggali potensi dan kemampuan yang tidak kalah dengan UMKM (Kartawan, 2016).

Maka dari itu, kelompok 41 KKN UNSIL 2020 bersama partisipan yang memberikan dukungan finansial, berharap program kerja pembuatan face shield tersebut sebagai wujud kepedulian terhadap produktivitas dan kreativitas masyarakat dalam meningkatkan pendapatan dan perekonomian masyarakat. Selain itu, harapannya masyarakat mampu belajar bagaimana cara implementasi promosi dan penjualan yang efektif dan efisien sehingga hasil kreativitas masyarakat mampu bersaing di dunia bisnis serta dapat dipasarkan secara luas.

Dalam dunia bisnis, perlu adanya kesadaran dari masyarakat bahwa meningkatkan skill dan juga pengetahuan itu sangatlah penting. Oleh karena itu, untuk meningkatkan bakat usaha dari masyarakat perum Bumi Endah Residence, kami melakukan penyuluhan terkait edukasi bisnis. Hal ini dilakukan supaya bisnis yang dibangun oleh masyarakat 
dapat memberikan manfaat bagi semua pihak serta mampu menghasilkan nilai yang lebih baik terutama dari sisi ekonomi mayarakat tersebut.

\section{METODE PELAKSANAAN}

Pelaksanaan kegiatan ini menggunakan metode penyuluhan dan pelatihan secara langsung kepada 5 orang ibu rumah tangga Perum Bumi Endah Residence. Ibu-ibu tersebut diberikan penyuluhan mengenai pentingnya berbisnis di masa pandemi, kemudian diberi pelatihan menganai cara memproduksi face shield tanpa mesin (hand made), kemudian ibu-ibu tersebut menjualkan hasil produksinya itu. Menurut Mardikanto (2009), penyuluhan merupakan suatu proses perubahan sosial, ekonomi dan politik dalam memberdayakan serta memperkuat kemampuan masyarakat melalui proses belajar bersama yang partisipatif, agar terjadi perubahan perilaku pada diri semua stakeholders (individu, kelompok, kelembagaan) yang terlibat. Waktu yang dibutuhkan untuk penyuluhan ini adalah selama 30 hari selama waktu KKN dengan waktu pertemuan selama 2 minggu. Minggu ke-1 sebagai kegiatan produksian, minggu ke-2 sebagai penjualan.

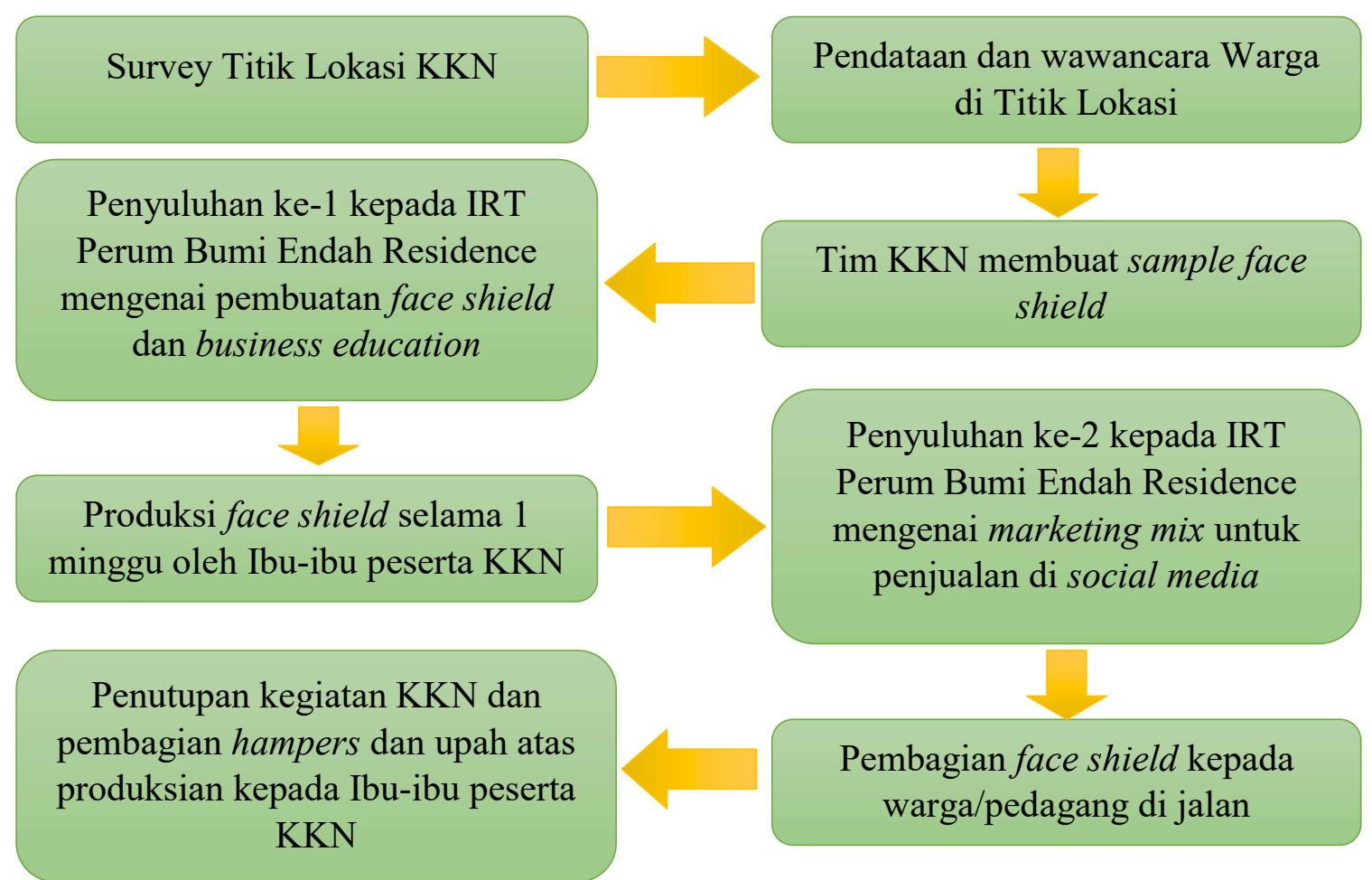

Gambar 1. Alur Kegiatan Pengabdian Pada Masyarakat 


\section{HASIL DAN PEMBAHASAN}

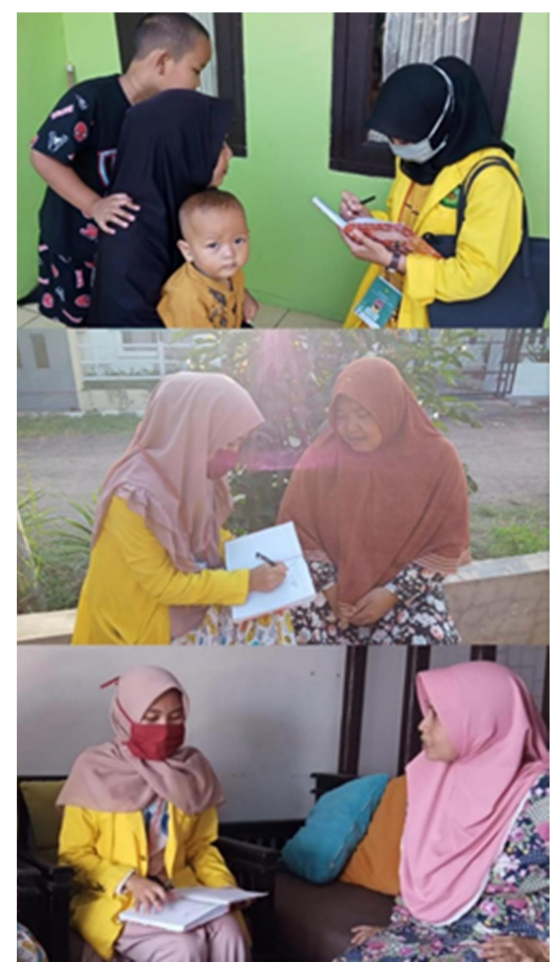

\section{Gambar 2. Tim KKN mendata dan wawancara warga target peserta KKN}

K.R. Soegijono,MS menyatakan: "Wawancara merupakan proses tanya lisan dimana dua orang atau lebih bertatap muka secara fisik untuk mengetahui taggapan, pendapat, dan motivasi seseorang terhadap suatu objek."

Pada Gambar 2, Tim KKN mendata warga khusunya ibu-ibu untuk dijadikan target peserta KKN Kelurahan Parakannyasag. Dari hasil Survey titik lokasi dan pendataan warga Pada tahap ini kami menemukan lokasi yang cocok untuk dijadikan tempat pelaksanaan kegiatan KKN yaitu berlokasi di Perum Bumi Endah Residence, Kelurahan Parakannyasag, Kecamatan Indihiang, Kota Tasikmalaya. Setelah itu, kami melakukan pendataan warga sebagai target dalam partisipan kegiatan KKN kami.

Tabel 1. Data Partisipan

\begin{tabular}{|l|l|l|}
\hline No. & \multicolumn{1}{|c|}{ Nama } & \multicolumn{1}{|c|}{ Pekerjaan } \\
\hline 1. & Ibu Kepi Nuryama & Ibu Rumah Tangga (IRT) \\
\hline 2. & Ibu Ina Rohina & Ibu Rumah Tangga (IRT) \\
\hline 3. & Ibu Euis Yulianti & Ibu Rumah Tangga (IRT) \\
\hline 4. & Ibu Rd. Mas Irma & Ibu Rumah Tangga (IRT) \\
\hline 5. & Ibu Santi Mulyanti & Ibu Rumah Tangga (IRT) \\
\hline
\end{tabular}


- Capaian: Terdapat 5 Kartu Keluarga yang terdata dan siap untuk berpartisipasi dalam pelaksanaan KKN selama 30 hari. Dimana terdapat 1 orang dari setiap Kartu keluarga.

- Kendala: Pada saat melakukan pendataan, terdapat kendala dalam menyampaikan maksud dan tujuan dari pelaksanaan KKN karena warga yang bersangkutan rata-rata memiliki seorang anak yang masih balita sehingga tidak memiliki banyak waktu luang untuk berkomunikasi

- Solusi: Mengadakan Penyuluhan untuk menyampaikan program kegiatan KKN, agar tersampaikan secara sistematik.

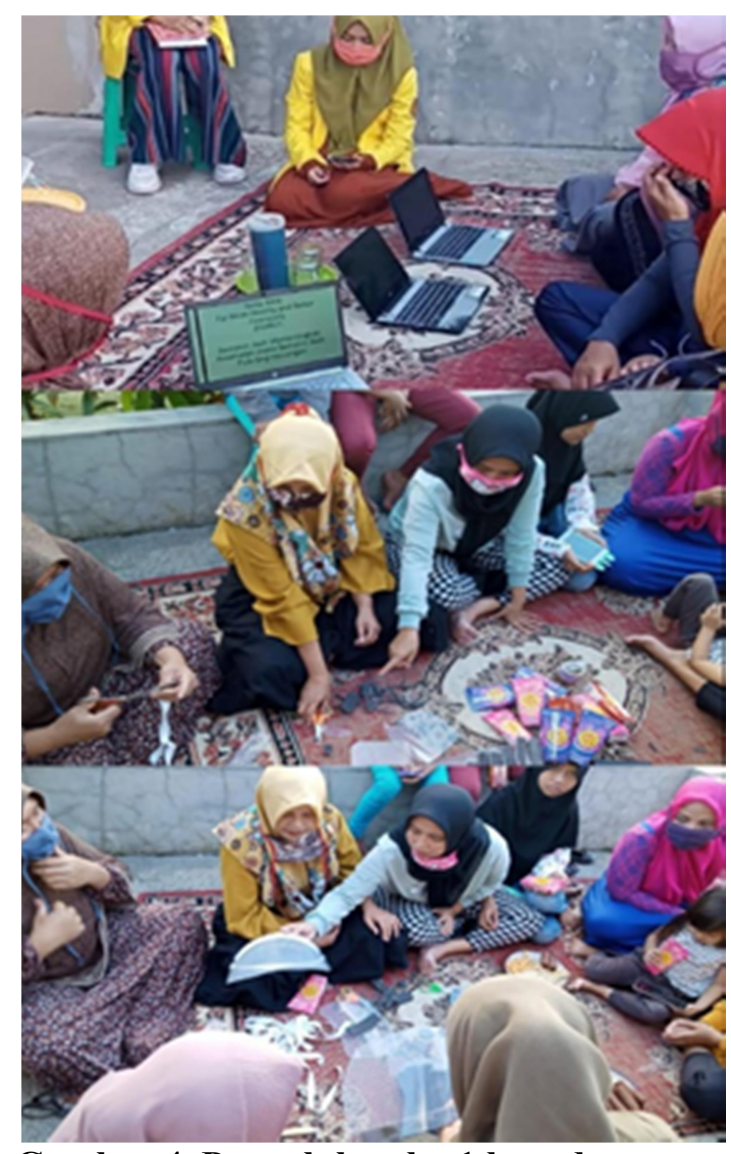

Gambar 4. Penyuluhan ke-1 kepada peserta KKN dan mulai pembuatan face shield

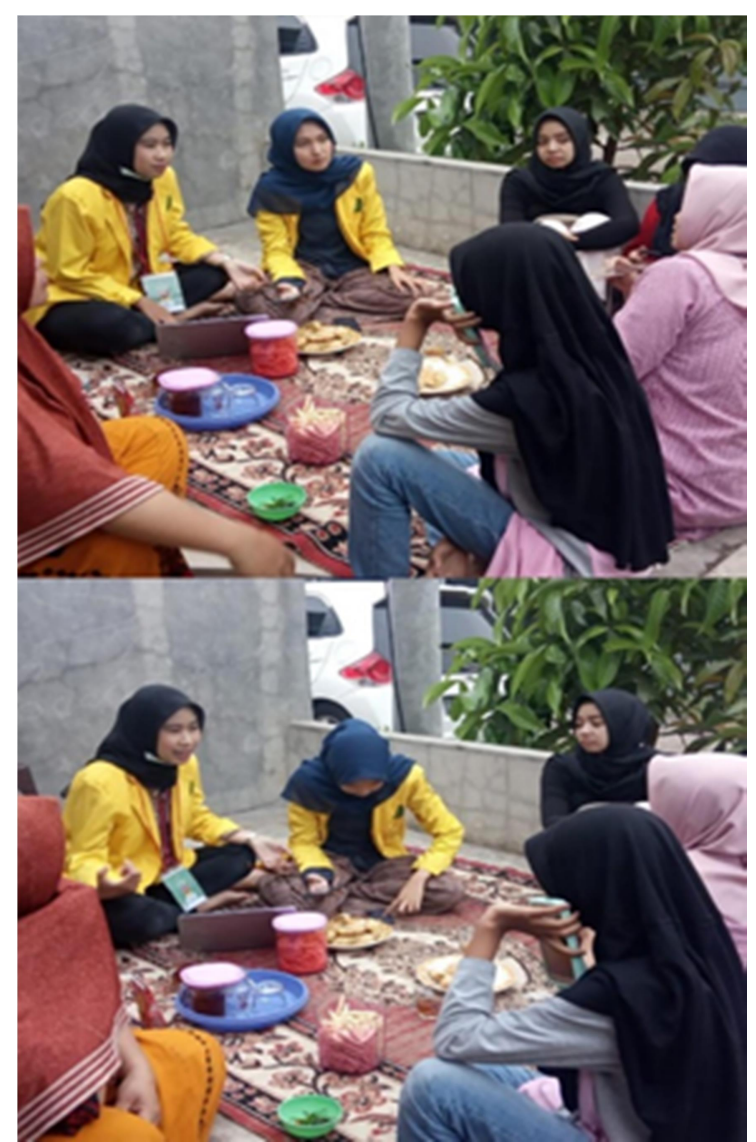

Gambar 5. Penyuluhan ke-2 kepada peserta KKN

Penyuluhan adalah manusia sebagai bagian dari sebuah sistem sosial, obyek materi ilmu. Penyuluhan adalah perilaku yang dihasilkan dari proses pendidikan dan atau pembelajaran, proses komunikasi dan sosial (Amanah, 2007).

\section{Penyuluhan Ke-1}

Pada penyuluhan ini materi yang disampaikan adalah mengenai Covid-19 yang didalamnya terdapat pembahasan mengenai pentingnya berbisnis di saat pandemi. Selain 
Meningkatkan Perekonomian Ibu Rumah Tangga dengan Menumbuhkan Minat Berwirausaha

itu, dalam penyuluhan ini pun diperlihatkan/dipraktekan cara pembuatan Face Shield terhadap warga yang tinggal di Perum Bumi Endah Residence, Kelurahan Parakannyasag, Kecamatan Indihiang, Kota Tasikmalaya agar mereka memahami dan dapat memproduksi Face Shield dengan baik ke depannya.

- Capaian: Warga mengetahui cara pembuatan Face Shield dalam waktu yang singkat. Kreativitas warga meningkat dalam membentuk produksian.

- Kendala: Ketepatan waktu dalam memulai acara, karena pada saat itu ada salah satu warga yang sedang melakukan aktivitas di luar rumah sehingga tidak datang tepat waktu.

- Solusi: Memberitahu/membuat kesepakatan bersama warga mengenai jadwal penyuluhan agar dapat terlaksana tanpa kendala apapun.

Ilmu penyuluhan bertujuan untuk memberdayakan masyarakat agar mereka mampu meningkatkan kesejahteraan dan kualitas hidupnya. (Bahua, MI. 2016). Dengan penyuluhan elemen perencanaan akan tercapai kepada sasaran yang dituju.

\section{Penyuluhan Ke-2}

Di penyuluhan ke-2 ini adalah Business Education dimana materi yang disampaikan adalah tentang penjualan bisnis online. Materi yang dibuat guna untuk memberikan pengetahuan kepada warga agar dapat menerima ilmu baru sehingga bisa dijadikan peluang untuk bahan pembelajaran dalam menjalankan sebuah bisnis. Terutama bisnis online, mengingat sekarang sedang berada dalam kondisi Covid-19 yang membatasi usaha secara tatap muka, maka peluang bisnis online jauh lebih besar hasilnya.

- Capaian: Warga memiliki rasa ingin tahu yang lebih tentang bagaimana cara berbisnis online agar penjualan bisa mencapai target.

- Kendala: Warga yang menjadi target rata-rata tidak mahir dalam mengoperasikan teknologi khususnya di bidang media sosial, sehingga penyampaian materi tidak cukup jika hanya dilakukan dalam waktu yang sebentar.

- Solusi: Melakukan bimbingan secara pribadi kepada setiap warga agar bisa mengoperasikan teknologi secara efektif dan efisien. 


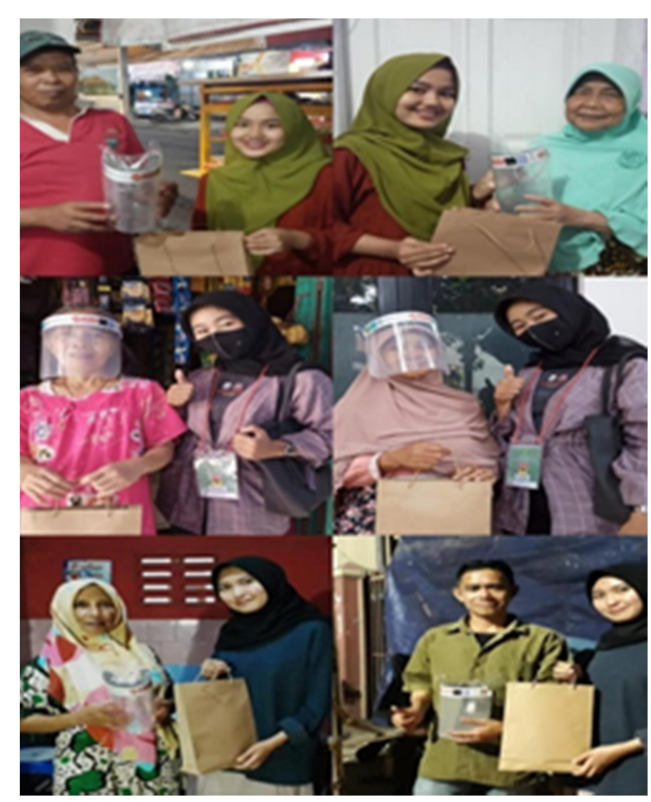

\section{Gambar 6. Tim KKN membagikan face shield kepada pedagang}

Pada Gambar 6. Tim KKN membagikan face shield hasil produksian ibu-ibu kepada warga sekitar dan pedagang. Dari kegiatan tersebut bertujuan agar tercapainya hasil yang maksimal dalam pencegahan virus korona terutama untuk warga yang sedang berjualan.
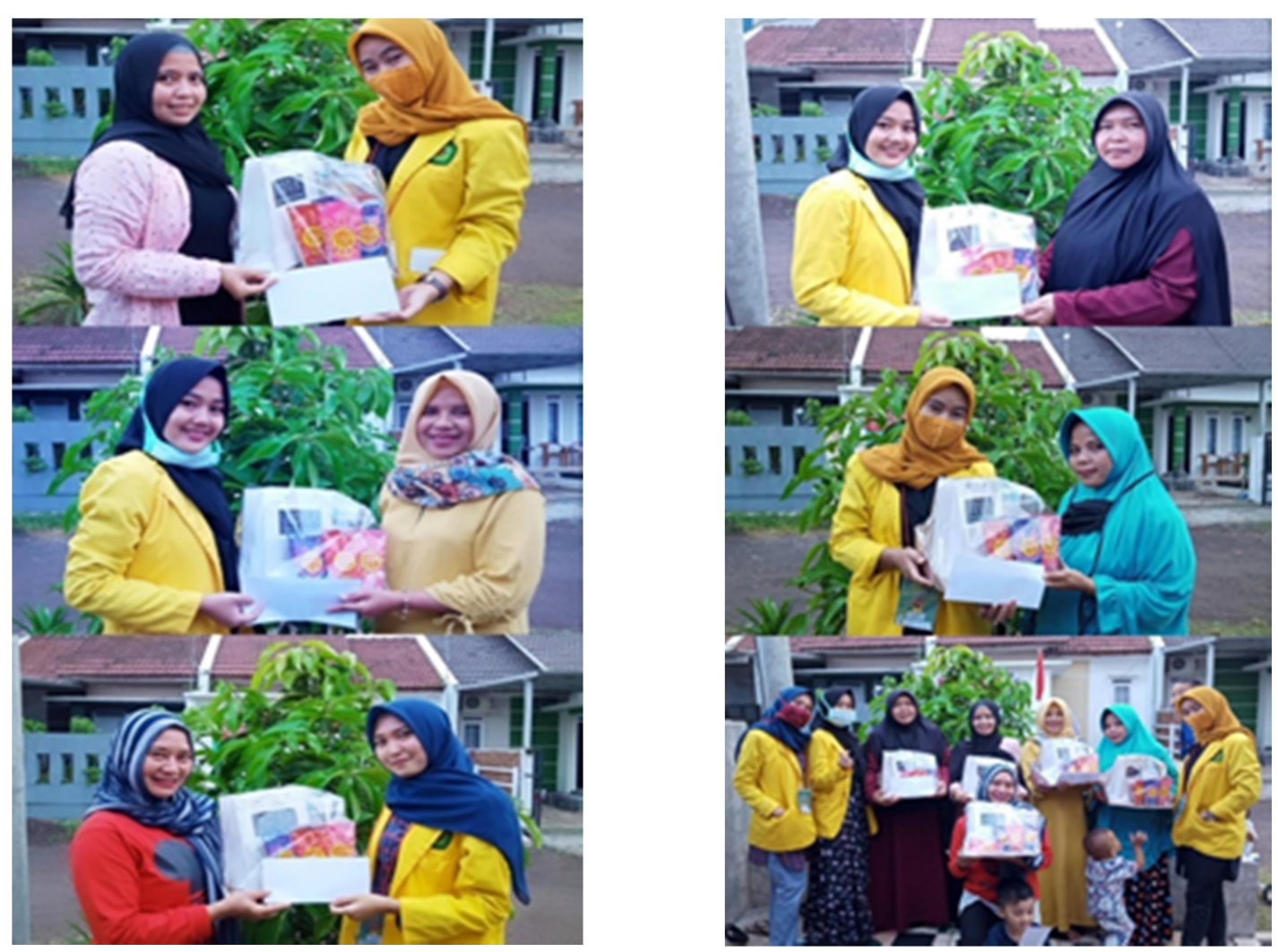

Gambar 7. Penutupan KKN diserta pembagian hampers dan upah produksian 
Meningkatkan Perekonomian Ibu Rumah Tangga dengan Menumbuhkan Minat Berwirausaha di Masa Pandemi Covid-19

Astri Handari, Indi Ramadhani, Tine Badriatin, Tasya Khoerunnisa Hijriah, Aulia Azizatul Jannah

Pada Gambar 5. TIM KKN Kelurahan Parakannyasag melaksanakan penutupan KKN yang diakhiri dengan pembagian souvenir beserta uang upah dari hasil produksian. Ibu-ibu melaksanakan produksi selama 1 minggu dengan upah $\mathrm{Rp} 50.000$,- dengan per hari memproduksi 5 face shield.

Dengan demikian, selain ibu-ibu bisa mendapatkan upah dari hasil produksinya, mereka juga bisa menjualkannya sendiri hasil kerja tangannya untuk memulai berbisnis. Sehingga ilmu yang sudah diberikan kepada ibu-ibu bisa bermanfaat. Selain itu, diharapkan dapat memberikan nilai tambahan untuk meningkatkan wawasan masyarakat dalam berwirausaha dan belajar mempromosikan produk sendiri agar dapat bersaing dan dipasarkan secara luas (Badriatin, 2018).

\section{KESIMPULAN DAN SARAN}

Berdasarkan kegiatan yang telah dilaksanakan dalam pengabdian pada masyarakat ini diperoleh kesimpulan bahwa meningkatkan perekonomian, minat dan kualitas berwirausaha di saat pandemi Covid-19 yang bisa menjadi nilai tambah bagi perekonomian keluarganya di Perum Bumi Endah Residence, Kelurahan Parakannyasag. Dengan keikutsertaan mahasiswa dalam upaya mendukung pencegahan Covid-19 di kelurahan tempat tinggal sendiri dapat membantu masyarakat dalam menanggulangi permasalahan umum seperti kesadaran masyarakat dalam meningkatkan kesehatan dalam penggunaan masker face shield karena dengan alasan pengganti masker kain yang sebagian orang merasa pengap dalam memakainya, meningkatkan kesadaran masyarakat untuk memulai bisnis serta membantu memecahkan permasalahan perekonomian keluarga di saat situasi pandemi. Solusi yang dapat diberikan mahasiswa selama KKN Mandiri dapat berupa pemecahan terhadap masalah yang bermunculan karena adanya pandemi Covid-19 serta mencari peluang-peluang yang dapat dijadikan solusi umtuk memecahkan permasalahan tersebut. Program kerja yang disusun selama KKN berdasarkan hasil survey dan identifikasi permasalahan yang terjadi saat ini untuk kemudian dirumuskan pemecahan masalahnya dan penyusunan strategi di setiap program kerjanya. Dalam pembuatan program kerja ini telah disesuaikan dengan keadaan di saat pandemi agar program kerja dapat bermanfaat bagi masyarakat di lingkungan KKN.

\section{UCAPAN TERIMA KASIH}

Terima kasih penulis ucapkan kepada rekan-rekan peserta Kelompok 41 KKN Mandiri UNSIL 2020 yang telah memberikan kontribusinya dalam kegiatan pengabdian 
pada masyarakat di Kelurahan Parakannyasag. Begitu juga kami sampaikan terima kasih kepada warga serta aparat Kelurahan Parakannyasag yang telah membantu semua kegiatan KKN Mandiri kelompok 41 Universitas Siliwangi 2020.

\section{DAFTAR PUSTAKA}

Amanah, S. Makna Penyuluhan dan Transformasi Perilaku Manusia. Vol 3, No.1, Maret 2007.

Isrososiawan, S. Peran Kewirausahaan dalam Pendidikan. Jurnal UIN Mataram, 4(1), Juni 2013. https://journal.uinmataram.ac.id/index.php/society/article/view/329.

Kartawan, Lucky Radi Rinandiyana, Dian Kurniawan. (2016). Pengembangan Usaha Melalui Peningkatan Kemampuan Bersaing Produk UMKM dalam Memasuki Masyarakat Ekonomi ASEAN. Jurnal Ekonomi Bisnis, 21(2): 104-110.

Mardikanto, Totok. (2009). Sistem Penyuluhan Pertanian. Universitas Sebelas Maret. Surakarta. 467 Hal.

Soegijono, MS. Wawancara Sebagai Salah Satu Metode Pengumpulan Data. Media Penelitian dan Pengembangan Kesehatan, 3(1), 157152, 1993.

Tine Badriatin, Lucky Radi Rinandiyana, Elis Listiana Mulyani. (2018). Pemasaran Produk UMKM Binaan pada Pasar Keuangan Rakyat. JMM : Jurnal Masyarakat Mandiri, 2(2): 149-153. 